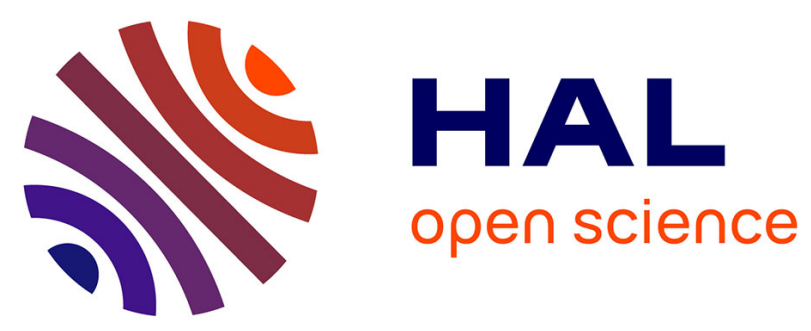

\title{
Tectonic Control on Rapid Late Miocene-Quaternary Incision of the Mekong River Knickzone, Southeast Tibetan Plateau
}

Anne Replumaz, Malwina San José, Audrey Margirier, Peter Beek, Cécile Gautheron, Philippe Hervé Leloup, Xiong Ou, Cao Kai, Guo-can Wang, Yuan-ze Zhang, et al.

\section{To cite this version:}

Anne Replumaz, Malwina San José, Audrey Margirier, Peter Beek, Cécile Gautheron, et al.. Tectonic Control on Rapid Late Miocene-Quaternary Incision of the Mekong River Knickzone, Southeast Tibetan Plateau. Tectonics, 2020, 39 (2), 10.1029/2019TC005782 . hal-02487244

\author{
HAL Id: hal-02487244 \\ https://hal.science/hal-02487244
}

Submitted on 29 Mar 2021

HAL is a multi-disciplinary open access archive for the deposit and dissemination of scientific research documents, whether they are published or not. The documents may come from teaching and research institutions in France or abroad, or from public or private research centers.
L'archive ouverte pluridisciplinaire HAL, est destinée au dépôt et à la diffusion de documents scientifiques de niveau recherche, publiés ou non, émanant des établissements d'enseignement et de recherche français ou étrangers, des laboratoires publics ou privés. 


\section{Tectonics}

\section{RESEARCH ARTICLE 10.1029/2019TC005782 \\ Key Points: \\ - New low-temperature thermochronology data show rapid Quaternary exhumation in the Mekong River knickzone, Southeast Tibet \\ - Both the amount of Quaternary exhumation and the pattern of river steepness point to a tectonic origin of the knickzone \\ - The exhumation history and topography around the knickzone are related to localized tectonic uplift associated with a restraining overstep between the Zhongdian and Parlung faults}

Correspondence to:

A. Replumaz,

anne.replumaz@univ-grenoble-alpes.fr

Citation:

Replumaz, A., San José, M., Margirier, A., van der Beek, P., Gautheron, C., Leloup, P. H., et al (2020). Tectonic control on rapid late MioceneQuaternary incision of the Mekong River knickzone, Southeast Tibetan Plateau. Tectonics, 39, e2019TC005782. https://doi.org/10.1029/2019TC005782

Received 21 JUL 2019 Accepted 22 JAN 2020

Accepted article online 29 JAN 2020

\section{Tectonic Control on Rapid Late Miocene-Quaternary Incision of the Mekong River Knickzone, Southeast Tibetan Plateau}

\author{
Anne Replumaz ${ }^{1}$ iD, Malwina San José ${ }^{2}$, Audrey Margirier ${ }^{3}$, Peter van der Beek ${ }^{1}$, \\ Cécile Gautheron $^{4}$, Philippe Hervé Leloup ${ }^{5}$ iD, Xiong Ou' ${ }^{1}$, Cao Kai ${ }^{6,7}$ iD, Guo-Can Wang ${ }^{6,7}$ (D), \\ Yuan-Ze Zhang' ${ }^{6}$, Pierre G. Valla ${ }^{1,8}$, and Mélanie Balvay ${ }^{1}$
}

${ }^{1}$ ISTerre, Université Grenoble Alpes, CNRS, IRD, Grenoble, France, ${ }^{2}$ Dipartimento di Scienze Geologiche, Universitá di Roma Tre, Rome, Italy, ${ }^{3}$ Institut für Erd- und Umweltwissenschaften, Universität Potsdam, Potsdam, Germany, ${ }^{4}$ GEOPS, Univ. Paris-Sud, CNRS, Université Paris-Saclay, Orsay, France, ${ }^{5}$ Laboratoire de Géologie de Lyon, CNRS, Université de Lyon 1, Villeurbanne, France, ${ }^{6}$ Hubei Key Laboratory of Critical Zone Evolution, Center for Global Tectonics, School of Earth Sciences, China University of Geosciences, Wuhan, China, ${ }^{7}$ State Key Laboratory of Geological Processes and Mineral Resources, China University of Geosciences, Wuhan, China, ${ }^{8}$ Institute of Geological Sciences and Oeschger Center for Climate Research, University of Bern, Bern, Switzerland

ABSTRACT The incision history of the Three Rivers (Salween, Mekong, and Yangtze) region in the Southeast Tibetan Plateau has been linked to both tectonic and climatic controls. In this study, we report new apatite (U-Th)/He and fission-track thermochronology data from the >6,000-m-high Kawagebo massif, which forms the edge of the high plateau on the western flank of the steepened knickzone reach of the middle Mekong River valley. Thermal-history modeling of a thermochronological age-elevation profile shows rapid cooling since $\sim 1.5 \mathrm{Ma}$ and suggests a mean Quaternary exhumation rate of $>1 \mathrm{~km} / \mathrm{Myr}$ at the valley bottom. The amount of Quaternary exhumation is too high to be caused by fluvial incision alone and requires additional tectonic uplift. Comparing our data from the western flank of the Mekong River valley with published data from the eastern flank shows differential exhumation across the valley in the late Miocene, with the western flank undergoing more exhumation, but relatively uniform exhumation in the Quaternary. We relate rapid exhumation since the late Miocene on the western flank of the Mekong valley and the high topography of the Kawagebo massif to localized tectonic uplift associated with a restraining (left stepping) overstep between the still-active right-lateral Parlung and Zhongdian strike-slip faults. The pattern of river steepness index across the knickzone also indicates that it results from locally focused uplift. Our results demonstrate the importance of detailed thermochronologic studies in this very active region to constrain the complex multiphase tectonic history before invoking any potential climatic forcing of river incision.

\section{Introduction}

The remarkable drainage patterns and deep gorges of the rivers incising the Southeast Tibetan Plateau (Figure 1) have attracted significant attention, as they are thought to contain information on the drainage evolution, uplift history, and uplift mechanisms of the plateau. Early studies of the incision history of rivers in Southeast Tibet (Clark et al., 2005; Ouimet et al., 2010) argued that the timing of incision closely tracks that of widespread plateau uplift since $15-10$ Ma. However, paleo-altimetry data suggest uplift of the Southeast Tibetan Plateau between the Eocene and the early Miocene (Gourbet et al., 2017; Hoke et al., 2014; Li et al., 2015; Wu et al., 2018), that is, before the inferred late Miocene onset of river incision, casting doubt on the direct link between plateau uplift and river incision (Liu-Zeng et al., 2008). Moreover, the timing and rate of Cenozoic river incision have been shown to vary significantly throughout Southeast Tibet (Liu-Zeng et al., 2018; McPhillips et al., 2015; Nie et al., 2018; Tian et al., 2014; Wang et al., 2018; Yang et al., 2016), which could be related to transient evolution of river profiles, climatic controls on incision rates, or local tectonic perturbations. Thermochronology data collected away from the main rivers have been interpreted in terms of major regional tectonic changes in Southeast Tibet during the Cenozoic, which undoubtedly influenced the evolution of the river network. These data generally show evidence for two phases of rapid exhumation the first one starting in the late Eocene or the Oligocene depending on the locality and
(C)2020. American Geophysical Union. All Rights Reserved. 


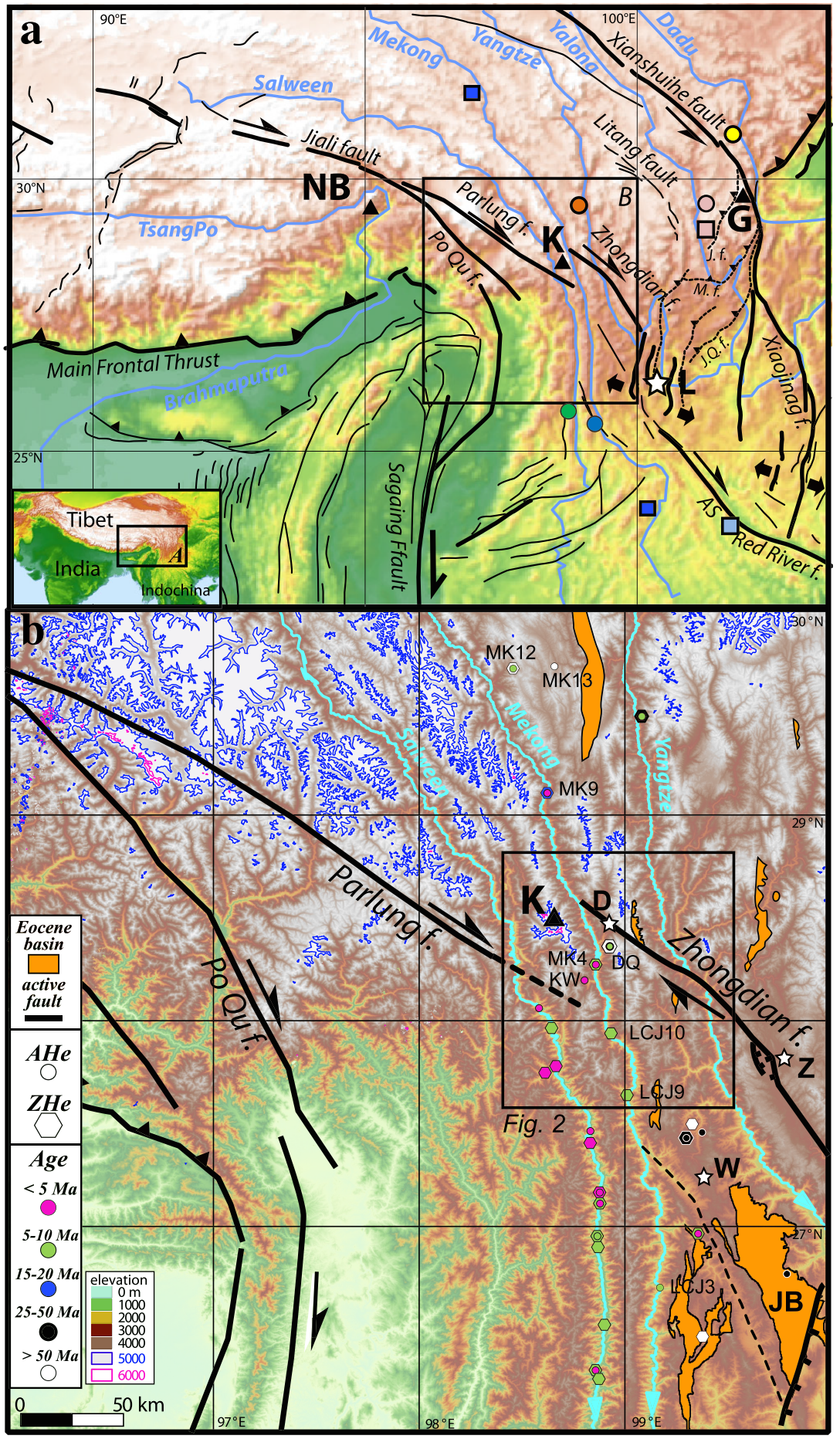

Figure 1. (a) Topographic map of the eastern Himalayan syntaxis region and Southeast Tibet (inset shows location of the study area within the Himalaya-Tibet system), showing major rivers in blue, major active faults in black (AS: Ailao Shan massif, along the Red River fault), inactive thrust faults in black dotted lines (Jiulong fault: J.f, Muli fault: M.f., and Jinhe-Qinghe fault: J.Q.f.) and highest summits as black triangles (NB: Namche Barwa, K: Kawagebo, and G: Gongga Shan). Regional compilation of AHe single-grain ages along elevation profiles (same color code as Figure 7). (b) Zoom on Three Rivers Region (see a for location). JB: Jianchuan basin. Sample codes for samples along the Mekong: KW: this study; DQ: Liu-Zeng et al. (2018), with only one symbol for each dataset (see Figure 3 for more detail); MK, LCJ: Yang et al. (2016). 
the second one starting in the Miocene, which are interpreted to be related to phases of compressive deformation (Cao et al., 2019; Liu-Zeng et al., 2018; Wang et al., 2012;Wang et al., 2016; Zhang et al., 2016). In contrast, present-day deformation in Eastern Tibet is dominated by strike-slip faults opening wide pull-apart basins (Figure 1). However, the dispersed nature of the available thermochronology data does not allow drawing definite conclusions regarding the origin of the observed variability in the timing and amount of exhumation throughout Southeast Tibet, considering its complex tectonic evolution. Unraveling the tectonic evolution of the region from its incision history requires a dense sampling strategy along the main rivers and their nearby massifs.

Here, we report new apatite (U-Th)/He (AHe) and fission-track (AFT) thermochronology data from the western flank of the middle Mekong River valley, combined with inverse modeling in order to reconstruct the Miocene to recent exhumation history of the region. The AHe and AFT systems allow constraining the thermal evolution of the upper $\sim 5 \mathrm{~km}$ of the crust, given their thermal sensitivity ranges spanning from $\sim 40-80^{\circ} \mathrm{C}$ to $\sim 60-120^{\circ} \mathrm{C}$, respectively (Flowers et al., 2009; Gallagher et al., 1998; Gautheron et al., 2009). The study area is located where the Mekong River forms a conspicuous large-scale knickzone (Yang et al., 2016), adjacent to the Kawagebo massif, the southernmost >6,000-m-high summit in Southeast Tibet (Figure 1). Valley-bottom samples show late Pliocene to Quaternary AHe ages, confirming earlier inferences of rapid recent incision in this river reach (Yang et al., 2016). Our data substantially add to the earlier studies, because the sampling density allows quantifying the amount, rate, and pattern of incision along the Mekong River knickzone. We compare our findings to other recent studies of incision along the Mekong River (Liu-Zeng et al., 2018; Nie et al., 2018; Yang et al., 2016) to map out the regional incision pattern. Finally, we discuss the potential tectonic or climatic controls on incision of the Mekong, linked to the tectonic evolution of Southeast Tibet.

\section{Geologic and Geomorphic Settings}

\subsection{Tectonics of Southeast Tibet}

Present-day deformation in Southeast Tibet is dominated by transtensional strike-slip faults opening wide pull-apart basins (Figure 1) and accommodating large-scale rotation around the Eastern Himalayan syntaxis (e.g., Bai et al., 2018; Gan et al., 2007). Close to the syntaxis, the right-lateral Jiali strike-slip fault splits into the ESE-trending Parlung fault and the SSE-trending the Po-Qu fault, which turns sharply around the syntaxis to link with the Sagaing fault (Figure 1a). Numerous massifs peaking at $>6,000 \mathrm{~m}$ occur between these two faults close to the syntaxis; farther to the east, the Parlung fault constitutes the southern limit of extensive >5,000-m-high massifs (Figure 1b). The ESE-striking Parlung fault terminates in the "Three Rivers" region of Southeast Tibet, where the Salween, Mekong, and Yangtze rivers flow from North to South in close proximity to each other. Here deformation is transferred along a restraining left-stepping overstep to the Zhongdian fault, a strike-slip fault with a clearly expressed subvertical fault planes and subhorizontal striations with right-lateral shear criteria, as observed west of Benzilan (Figure 2b) and northwest of Deqing at the western extremity of the fault. In the stepover region, the Kawagebo massif forms the southernmost $>6,000$-m-high massif in Southeast Tibet (Figure 1b). Farther to the southeast, the Zhongdian fault links to the Red River fault, along a right-stepping overstep, through the Lijiang pull apart (Figure 1). The Lijiang pull apart and associated right-lateral motion along the Red River fault have been estimated to be active since at least $5 \mathrm{Ma}$ and possibly since $14 \mathrm{Ma}$ (Fyhn \& Phach, 2015; Leloup et al., 1993; Replumaz et al., 2001; Schoenbohm et al., 2006; Wang et al., 2016). Farther from the syntaxis, the left-lateral Xianshuihe strike-slip fault system has been estimated to be active since 9 Ma (Zhang et al., 2017). At present, the Xianshuihe fault continues to the south along the Xiaojiang fault, which abuts the Red River fault trace (Replumaz et al., 2001; Schoenbohm et al., 2006). In between these two major faults, the left-lateral transtensional Litang fault has been active since 7-5 Ma and has opened numerous pull-apart basins (Zhang et al., 2015).

Prior to the middle Miocene, deformation in Southeast Tibet was dominated by NW-SE left-lateral strike-slip faults, the major one being the Ailao Shan-Red River ductile shear zone bordering the Red River fault, which accommodated extrusion of the Indochina block between 34 and 17 Ma (Leloup et al., 1995, 2001; Replumaz \& Tapponnier, 2003). To the southeast, the shear zone has been exhumed by the post extrusion reverse right-lateral Red River fault, forming the Ailao Shan massif (Leloup et al., 2001; Replumaz et al., 2001). Within the Ailao Shan massif, a rapid exhumation phase is recorded between 27 and $\sim 17 \mathrm{Ma}$, that 


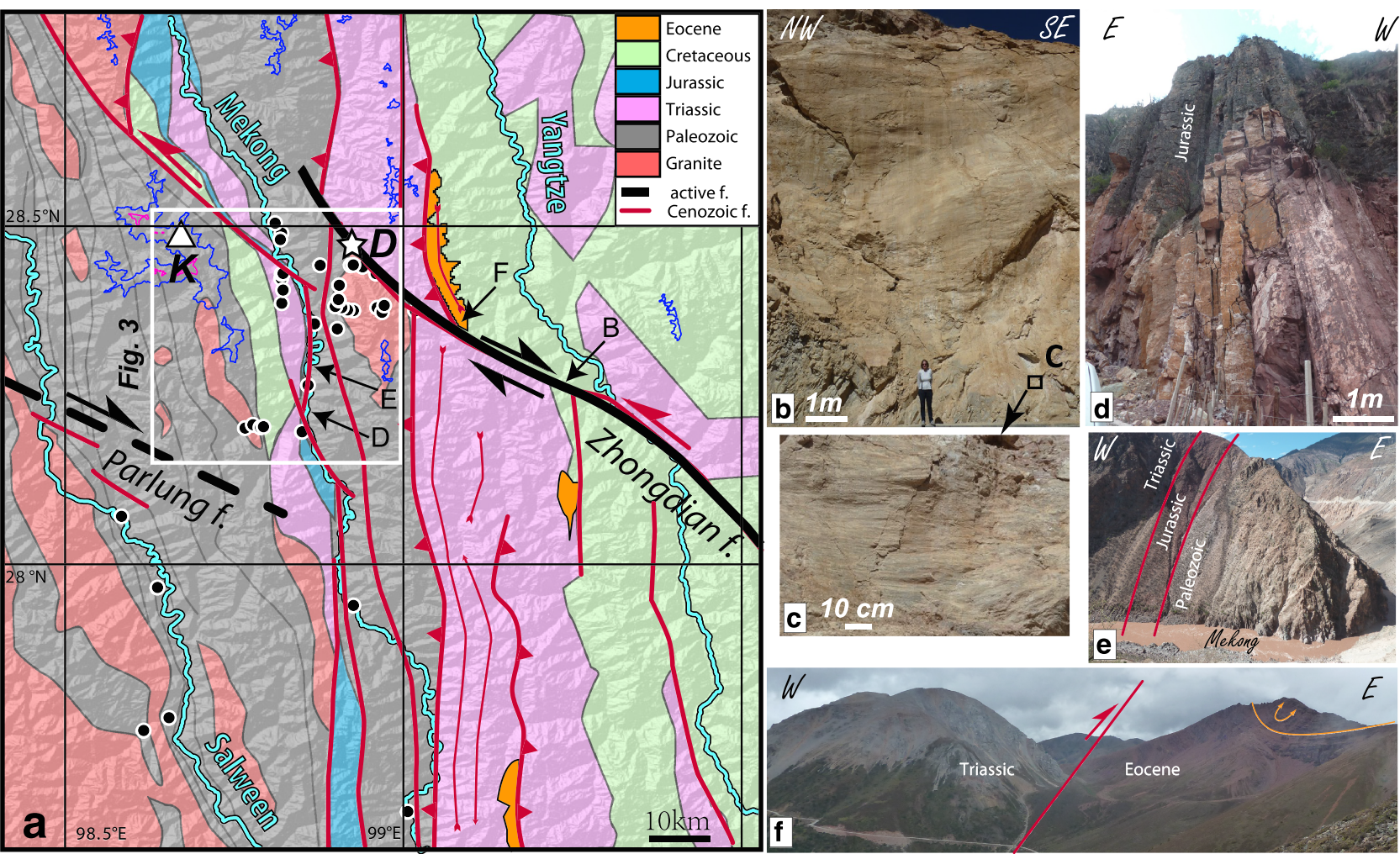

Figure 2. (a) Geologic map of the Kawagebo region (white triangle K: Kawagebo; white star D: Deqing; f.: fault; half arrows show current sense of motion on faults). Arrows indicate location of field photos b-f; white box shows location of Figure 3; black dots are sample location. (b) Subvertical fault plane of the Zhongdian fault between the Yangtze and the Mekong rivers trending N120. (c) Subhorizontal striations consistent with the current right-lateral sense of motion (see location in b). (d) Jurassic unit following the Mekong River, with a typical red-wine color. This unit is only few 100-m wide and trends N-S with mostly subvertical stratification. (e) Same unit visible in a curve of the Mekong River along the Kawagebo massif, framed by Triassic and Paleozoic rocks. (f) Triassic rocks overthrusting an Eocene basin and associated folding of the basin strata, near Deqing.

is, contemporaneous to extrusion, with later postextrusion exhumation occurring since $14 \mathrm{Ma}$ (Wang et al., 2016). The switch of shear sense from left-lateral to right-lateral reflects a $90^{\circ}$ rotation of the shortening direction from $\sim \mathrm{E}-\mathrm{W}$ to $\sim \mathrm{N}-\mathrm{S}$ in the middle Miocene (e.g., Leloup et al., 1995). To the northwest of the Ailao Shan, the fault zone has been interpreted to broadly extend for more than $400 \mathrm{~km}$ along the Mekong River (Leloup et al., 1995), following a highly elongated Jurassic clastic unit with a distinctive red-wine color that dips vertically and trends N-S (Figures $2 \mathrm{~d}$ and 2e). This unit is offset by NW-SE leftlateral faults, the most prominent of which is the Zhongdian fault occuring immediately north of the Kawagebo massif (Figure 2a). These left-lateral faults are interpreted to be associated to a compressive phase accommodating large-scale uplift and thickening of Southeast Tibet coevally with Indochina extrusion (LiuZeng et al., 2008). If the finite offset on the Zhongdian fault is indeed left-lateral (Figure 2a), the present-day fault planes exhibit right-lateral shear criteria (Figure 2c), then a shear sense inversion comparable to that documented along the Red River fault is implied. The Jianchuan basin, located between the Mekong and Yangtze rivers (Figure 1b), was filled rapidly with Paleogene sediments between 37 and $35 \mathrm{Ma}$ (Gourbet et al., 2017), suggesting significant uplift and erosion in the source region. The strata were subsequently deformed and exhumed by thrusting between $\sim 28$ and $20 \mathrm{Ma}$ (Cao et al., 2019). Small basin strata remnants, mapped as Eocene (in orange in Figure 2a), are thrusted and folded by a series of regional north-south trending faults (Figure 2f). These faults bound topographic crests with elevations $>5,000 \mathrm{~m}$, significantly higher than the mean plateau elevation of $\sim 4,500 \mathrm{~m}$ (Figure 1). The highest of these crests forms the Kawagebo massif with elevation $>6,000 \mathrm{~m}$. Some of the thrusts east of the Jianchuan basin were later reactivated as normal faults coevally with the shear sense inversion of the Zhongdian fault, forming the Lijiang pull-apart basin (Cao et al., 2019). 


\subsection{The Mekong River and the Three Rivers Region}

The Salween (Nu), Mekong (Lancang), and Yangtze (Jinsha) rivers flow southeastward from the core of the Tibetan Plateau around the eastern Himalayan syntaxis (Figure 1). In the so-called Three Rivers region, these three rivers flow parallel to each other with a spacing of only a few tens of kilometer, a pattern that has been interpreted either as resulting from complex drainage evolution through multiple capture events (Clark et al., 2004) or as indicating preexisting drainages subjected to strong east-west shortening around the syntaxis (Hallet \& Molnar, 2001; Yang et al., 2015). The Salween and Mekong Rivers show conspicuous steep knickzones where they cross the Three-Rivers region, between 1,500- and 3,000-m elevation, whereas the Yangtze River shows a less-developed knickzone in the same region (Liu-Zeng et al., 2008; Nie et al., 2018; Yang et al., 2016).

The parallel north-south course of these rivers in the Three Rivers region appears structurally guided by north trending (currently inactive) faults with similar left-lateral offsets as the geological units (Figure 2), which suggests that these rivers were already in place before the middle Miocene change of the shortening direction. Peculiar drainage patterns (hairpin loops) of the lower channel of the Mekong River in Burma and Thailand record similar slip-sense inversion of strike-slip faults (Lacassin et al., 1998), also suggesting that the river was in place before the middle Miocene tectonic inversion in the region.

\subsection{Incision and Exhumation in the Three Rivers Region}

Yang et al. (2016) presented AHe, AFT, and zircon (U-Th)/He (ZHe) data from the Salween, Mekong and Yangtze river valleys that record an eastward decrease in the magnitude and rate of erosion (Figure 1b). Yang et al. (2016) interpreted their exhumation data as recording tectonic uplift associated with the northward advance of the Indian indenter corner, which would have caused northward migration of rapid exhumation toward the plateau interior and a westward increase in exhumation rates toward the Eastern Himalayan syntaxis. However, this interpretation was based on relatively sparse sampling, mainly focused on the valley bottoms, which does not provide sufficient spatiotemporal resolution on exhumation rates. Liu-Zeng et al. (2018) presented AHe, AFT, and ZHe data collected along an elevation profile in the Mekong knickzone near Deqing (Figure 1b). They interpreted these data as showing two Cenozoic phases of rapid exhumation, one between 60 and $40 \mathrm{Ma}$ and the other since $20 \mathrm{Ma}$. The first phase was suggested to be associated with the main uplift phase of the southeastern margin of the Tibetan Plateau and the second phase as delayed incision of the margin. Finally, Nie et al. (2018) presented AHe ages clustering around 20$15 \mathrm{Ma}$, from both downstream and upstream of the knickzone (Figure 1a). Nie et al. (2018) interpreted these data as recording middle Miocene initiation (or acceleration) of Mekong River incision due to an increase in monsoonal precipitation at that time.

\section{Methods: Low-Temperature Thermochronology and Thermal History Modeling}

We collected 11 samples for AHe and AFT thermochronology from the Mekong River valley in the knickzone region around Deqing and the adjacent Kawagebo massif (Figure 3). Sampling focused on a northern transect near the village of Ninong, on both valley flanks of the Mekong, and a southern transect near the village of Yongzhi, along a west-bank tributary incising the Kawagebo massif. The southern transect was collected exclusively in basement granites, whereas sampled rocks in the northern transect were mostly Paleozoic and Jurassic clastic sediments. AHe and AFT dating methods are detailed in the repository material. Thermal histories were determined from the AHe and AFT data from this study, complemented with ZHe data from the Mekong valley bottom previously reported by Yang et al. (2016), using the QTQt code. QTQt uses a Markov-Chain Monte-Carlo method to invert thermochronological ages for multiple samples with a known altitudinal relationship (Gallagher, 2012), employing an alpha-damage-dependent kinetic model of helium diffusion in apatite (Flowers et al., 2009), a multikinetic AFT annealing model (Ketcham et al., 2007), and helium diffusion parameters for zircon (Reiners \& Brandon, 2006). The input parameters used to model the temperature history of each profile are the single-grain AHe data, including grain sizes and $\mathrm{He}, \mathrm{U}$, Th, and Sm content and the AFT data (see repository material). 


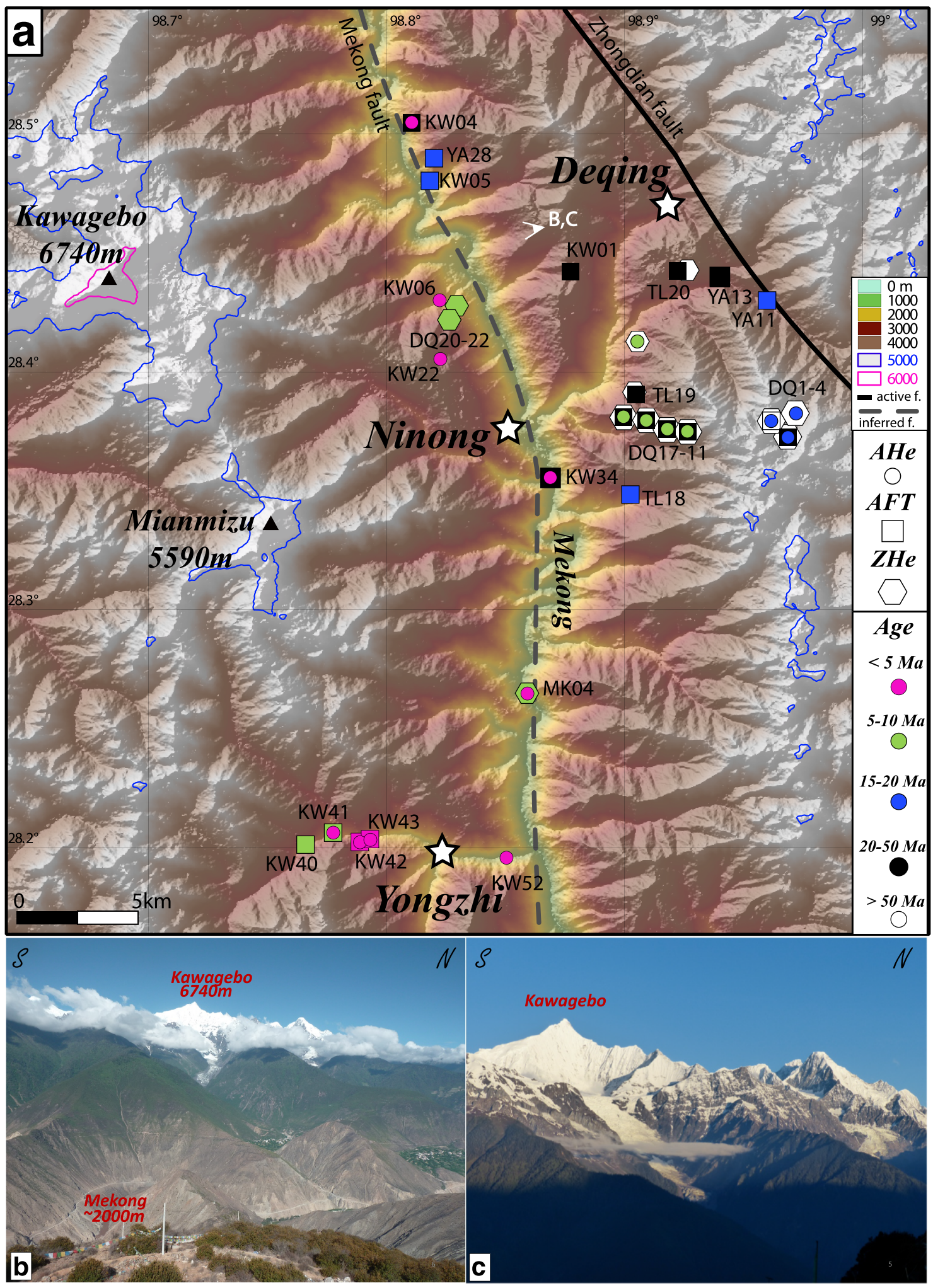

Figure 3. (a) Topographic map of the study area (see Figure 2a for location), with sample locations (KW: this study; YA: Wilson \& Fowler, 2011; MK, LCJ: Yang et al., 2016; DQ, TL: Liu-Zeng et al., 2018); symbols indicate different thermochronometers; colors indicate age (see legend). Blue and purple contours show 5,000and 6,000-m elevation, respectively. f.: fault. (b and c) Views of the Mekong valley and the Kawagebo summit taken from near KW01 sampling site showing the exceptionally deep valley (see panel a for location). 
Table 1

Synthesis of New Thermochronology Data ${ }^{a}$

\begin{tabular}{|c|c|c|c|c|c|c|c|c|c|}
\hline Sample & Longitude $\left({ }^{\circ} \mathrm{E}\right)$ & Latitude $\left({ }^{\circ} \mathrm{N}\right)$ & Elev. (m) & AHe age (Ma) & $1 \sigma$ & \# replicates & AFT age (Ma) & $1 \sigma$ & \# grains \\
\hline KW01 & 98.8773 & 28.4420 & 3463 & - & - & - & 36.3 & 17.1 & 18 \\
\hline KW04 & 98.8106 & 28.5049 & 2562 & 3.0 & 1.4 & 4 & 24.3 & 11.4 & 20 \\
\hline KW05b & 98.8182 & 28.4805 & 2350 & - & - & - & 14.8 & 9.5 & 16 \\
\hline KW06 & 98.8223 & 28.4301 & 2504 & 2.2 & 0.2 & 3 & - & - & - \\
\hline KW22 & 98.8226 & 28.4054 & 3443 & 3.9 & 0.4 & 1 & - & - & - \\
\hline KW34 & 98.8688 & 28.3556 & 2115 & 2.2 & 0.2 & 5 & 33.7 & 17.9 & 7 \\
\hline KW40 & 98.7660 & 28.2013 & 2911 & - & - & - & 6.1 & 2.5 & 17 \\
\hline KW41 & 98.7776 & 28.2063 & 2694 & 2.7 & 0.8 & 3 & 5.6 & 1.0 & 20 \\
\hline KW42 & 98.7888 & 28.2022 & 2573 & 2.9 & 1.1 & 4 & 3.0 & 0.8 & 16 \\
\hline KW43 & 98.7932 & 28.2033 & 2429 & 1.5 & 0.4 & 4 & 3.2 & 1.2 & 20 \\
\hline KW52 & 98.8503 & 28.1982 & 2060 & 1.2 & 0.1 & 4 & - & - & - \\
\hline
\end{tabular}

${ }^{\mathrm{a}}$ Note that apatite (U-Th)/He (AHe) ages reported here are arithmetic means of the single-grain replicate ages; see supplementary information (repository material) for individual grain ages and note that the AHe age of sample KW22 is from one replicate only. Apatite fission-track (AFT) ages are reported as central ages with $1 \sigma$ uncertainty; see repository material for detail. In blue, data used for QTQt modeling (Figure 5).

\section{Results: Timing and Rate of Exhumation in the Kawagebo Massif}

\subsection{New Thermochronology Data}

We obtained eight AFT and 28 single-grain AHe ages from 11 samples (Table 1); six from the northern transect near the village of Ninong, and five from the southern transect near the village of Yonzhi (Figure 3). Whereas the granitic rocks of the southern transect yielded apatite grains of excellent quality for AHe dating, the sedimentary rocks of the northern transect yielded less apatite grains, and of lesser quality.

The lowest-elevation samples close to the Mekong River (KW34, 52) show homogeneous single-grain AHe ages between $1.1 \pm 0.1$ and $1.7 \pm 0.2 \mathrm{Ma}$; age dispersion is within analytical error (Figure 4). Near Yonzhi village, the highest-elevation samples (KW41, 42) show more scattered single-grain ages between $2.0 \pm 0.2$ and 3.8 \pm 0.3 Ma. AFT ages have large error bars (Table 1), mostly because of the young ages and low U content (see repository material). Near Yongzhi, AFT ages are between $3.0 \pm 0.8$ and $6.1 \pm 2.5 \mathrm{Ma}$, older than AHe ages and younger than the published ZHe age of 7.6 $\pm 0.5 \mathrm{Ma}$ (sample MK04; Yang et al., 2016; Figure 3). On the west flank of the Mekong valley near Ninong, only sample KW-06 yielded sufficient apatites for AHe dating, with single-grain AHe ages of $1.8 \pm 0.2$ to $2.8 \pm 0.3 \mathrm{Ma}$. Sample KW-22 provided a single suitable apatite grain with an AHe age of 3.9 \pm 0.4 Ma. On the eastern valley flank, sample KW04 yielded single-grain AHe ages of $1.8 \pm 0.2$ to $4.4 \pm 0.4 \mathrm{Ma}$. AFT ages are scattered between $15 \pm 10$ and $36 \pm 17$ Ma, with large error (Table 1).

\subsection{Time-Temperature Histories}

We performed thermal-history modeling of the Yongzhi profile, which has the most complete dataset with both high-quality AHe data and consistent AFT ages on four samples. All samples have been collected from the western flank of the Mekong valley in a crustal block without obvious active faults. In addition, we used a published ZHe age (sample MK04; Yang et al., 2016), located close to our profile along the Mekong River, to better constrain the late Miocene thermal history. The model results suggest a three-phase cooling history (Figure 4): (1) late Miocene to early-Pliocene (i.e., between at least $\sim 8$ and $4 \mathrm{Ma}$ ) rapid cooling with a mean rate of $\sim 27^{\circ} \mathrm{C} / \mathrm{Myr}$ (with large associated uncertainties of +7.5 and $-15^{\circ} \mathrm{C} / \mathrm{Myr}$ ); (2) a relatively quiescent phase between 4 and $1.5 \mathrm{Ma}\left(0 \pm 5^{\circ} \mathrm{C} / \mathrm{Myr}\right)$; and (3) very rapid cooling since $\sim 1.5 \mathrm{Ma}$, well constrained at a maximum rate of $56 \pm 5^{\circ} \mathrm{C} / \mathrm{Myr}$ for the lowest sample (KW52), and a minimum rate of $33 \pm 7{ }^{\circ} \mathrm{C} / \mathrm{Myr}$ for the highest sample (KW41). The single-grain age dispersion obtained from the modeling reproduces the observed data, showing that the model predictions in terms of timing and rate of cooling are robust (Figure 4). In particular, the dispersed single-grain AHe ages in the higher-elevation samples (KW41 and KW42) result from the relatively quiescent phase between 4 and 1.5 Ma, when these samples resided at a temperature of $\sim 60{ }^{\circ} \mathrm{C}$, whereas the lowermost sample only cooled through the AHe partial retention zone after 1.5 Ma.

The apparent geothermal gradient between the highest and lowest AHe samples is estimated at $\sim 55^{\circ} \mathrm{C} / \mathrm{km}$ (elevation difference of $0.63 \mathrm{~km}$ and temperature difference of $\sim 35^{\circ} \mathrm{C}$ ). Similar near-surface geothermal 

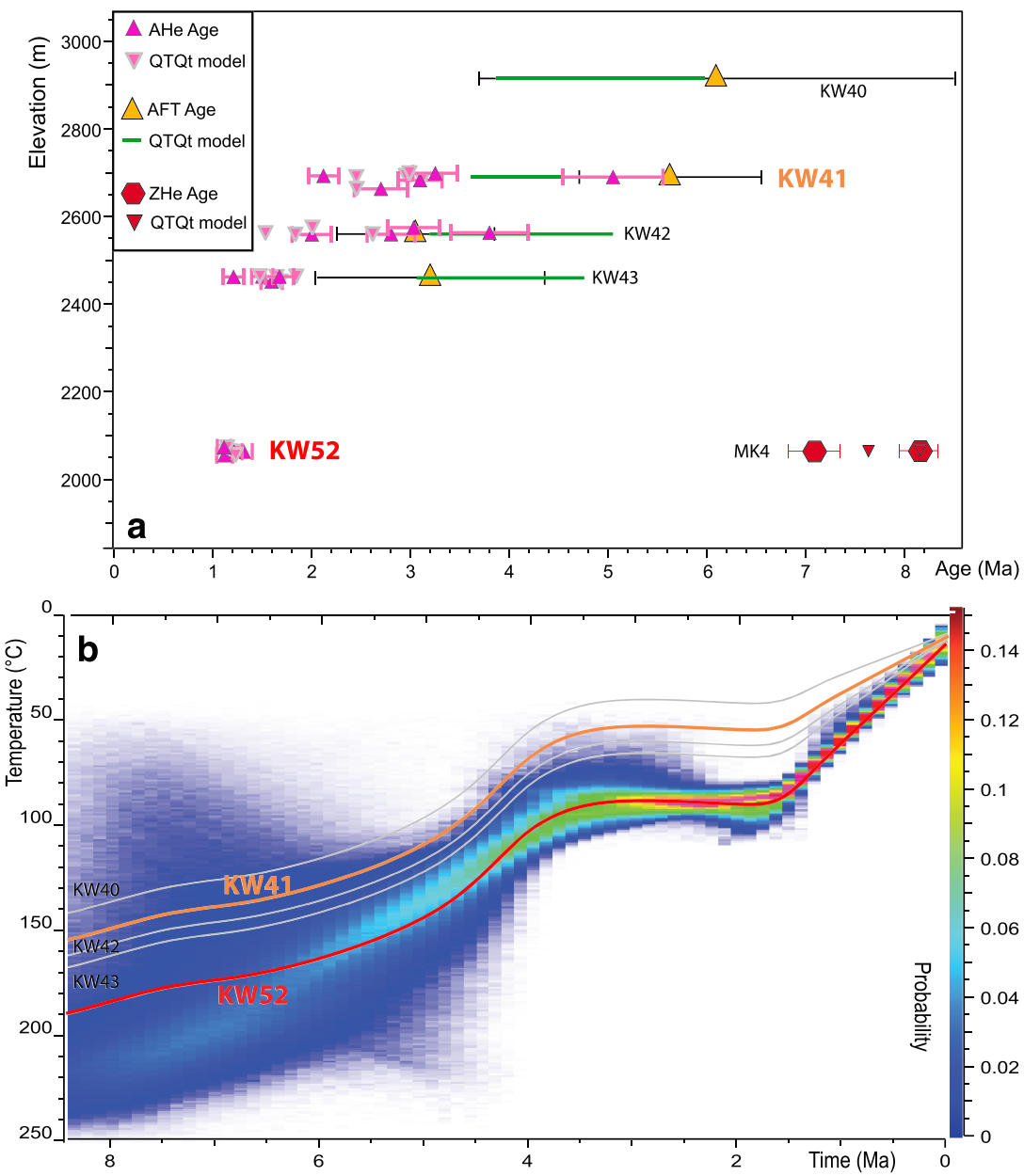

Figure 4. (a) Age-elevation relationship for the Yongzhi profile, showing both observed and model (QTQt) predicted ages (single-grain ages for AHe, central ages for AFT). (b) Thermal modeling results for five samples of the Yongzhi profile; grey (KW40, KW42, and KW43), orange (KW41), and red (KW52) lines annotated with the sample name indicate the most probable thermal history, on top of a single-sample thermal-history model for the lowest sample (KW52) with probability indicated by colors (scale on the right).

gradients exceeding $50{ }^{\circ} \mathrm{C} / \mathrm{km}$ have been reported for the rapidly exhuming ( $>5 \mathrm{~km} / \mathrm{Myr}$ ) Namche Barwa massif in the eastern Himalayan syntaxis (Craw et al., 2005). With such a gradient, the Quaternary exhumation rate would be $1.0 \pm 0.1 \mathrm{~km} / \mathrm{Myr}$ for the lowest (KW52) and $0.6 \pm 0.1 \mathrm{~km} / \mathrm{Myr}$ for the highest sample (KW41), corresponding to total exhumation since $1.5 \mathrm{Ma}$ of $1.5 \pm 0.2 \mathrm{~km}$ and $0.9 \pm 0.2 \mathrm{~km}$, respectively. However, this high apparent geothermal gradient does not account for the lateral offset of $\sim 7 \mathrm{~km}$ between the samples and should be considered as a maximum; the associated exhumation rates and total amounts are therefore minimum values. A more probable value for the geothermal gradient would be of the order of $40{ }^{\circ} \mathrm{C} / \mathrm{km}$; such a value has been inferred by thermal-kinematic inversion of thermochronology data from the Gongga Shan massif in Eastern Tibet (Zhang et al., 2017). With this gradient, the maximum Quaternary exhumation rate would be $1.4 \pm 0.1 \mathrm{~km} / \mathrm{Myr}$ for the lowest sample (KW52), corresponding to $2.1 \pm 0.2 \mathrm{~km}$ of exhumation since $1.5 \mathrm{Ma}$, and $0.8 \pm 0.2 \mathrm{~km} / \mathrm{Myr}$ for the highest sample (KW41), corresponding to $1.2 \pm 0.3 \mathrm{~km}$ of exhumation.

\section{Discussion: Exhumation and Incision Along the Mekong River}

\subsection{Comparison of Exhumation Histories Across the Mekong Middle Reach}

We compare our data obtained from the west flank of the Mekong valley (Yongzhi profile) with recently published AHe, AFT, and ZHe ages from the eastern valley flank in the same area (Deqing profile, samples indicated DQ and TL in Figure 3; Liu-Zeng et al., 2018). Data from the eastern flank (Liu-Zeng et al., 2018) 
were collected at higher elevations, between 3,000 and 5,000 m, relative to our samples, which were collected between 2,000 and 3,000 m (Figure 5a). Comparison of our AHe ages with those from Liu-Zeng et al. (2018) shows a rather continuous age-elevation relationship (Figure 5a), suggesting uniform cooling of both flanks of the Mekong River valley. In contrast, ZHe ages show a clear jump across the valley, from late Miocene (DQ20: $7.9 \pm 1.2 \mathrm{Ma}$; DQ22: $16 \pm 13 \mathrm{Ma}$ ) on the western flank, to Cretaceous $(100-80 \mathrm{Ma})$ on the eastern flank (Figures 3 and $6 \mathrm{~b}$ ). The ZHe ages from the western flank are consistent with an age obtained by Yang et al. (2016), $10 \mathrm{~km}$ farther south (MK04; $7.6 \pm 0.5 \mathrm{Ma}$ ). A comparison of the AFT ages from the Yongzhi profile (KW 40, 41, 42, 43: $3 \pm 0.8$ to $6 \pm 2.5 \mathrm{Ma}$ ) with those at similar elevations $(2,400-2,900 \mathrm{~m})$ from the eastern flank of the valley around Deqing (i.e., samples KW01, KW04, KW05, and KW34 from this study: $15 \pm 10$ to $36 \pm 17 \mathrm{Ma}$; sample YA28 from Wilson and Fowler (2011): $11 \pm 4$ Ma; TL09-18/19 from LiuZeng et al. (2018): $15 \pm 1 / 21 \pm 1 \mathrm{Ma}$ ) also suggests a jump in AFT ages across the valley (Figures 3 and $6 \mathrm{~b}$ ). Therefore, the AFT and ZHe data record differential exhumation across the Mekong valley in the late Miocene, with the western flank undergoing more exhumation. In contrast, the AHe data suggest a more recent uniform pattern of exhumation on both flanks of the valley (Figures 5a and 6b).

Liu-Zeng et al. (2018) interpreted their data using a stacked age versus pseudo-elevation profile, assuming a geothermal gradient of $30{ }^{\circ} \mathrm{C} / \mathrm{km}$ and inferred that the eastern flank of the Mekong River experienced an early Cenozoic phase of rapid exhumation at $\sim 40 \mathrm{Ma}$ and a second phase since $\sim 20 \mathrm{Ma}$, with a possible acceleration since 5-4 Ma. We modeled the AHe and AFT data of Liu-Zeng et al. (2018), using the same approach as for our samples from the western flank, to compare the exhumation histories across the Mekong valley more quantitatively. We included all AFT ages (TL and DQ samples) but only the single-grain AHe ages (DQ samples) from the eastern flank of the valley in this inversion. The resulting thermal history (repository material) shows that the inferred early phase at $\sim 40 \mathrm{Ma}$ is not well constrained by the dataset and is not reproduced by our modeling. Our thermal-history modeling of these data predicts a rapid cooling phase between 80 and $50 \mathrm{Ma}$ followed by slow cooling since $\sim 50 \mathrm{Ma}$. The Miocene to recent history is characterized by a rapid cooling phase between $\sim 10$ and $8 \mathrm{Ma}$ and by a final phase of rapid cooling since $\sim 2 \mathrm{Ma}$ (Figures $6 \mathrm{a}$ and repository material). The Miocene phase of cooling east of the Mekong valley occurs somewhat earlier $(\sim 10-8 \mathrm{Ma}$ vs. $\geq 8-4 \mathrm{Ma})$ and a lesser amount $\left(\sim 25-30{ }^{\circ} \mathrm{C}\right.$ vs. $\left.\sim 100{ }^{\circ} \mathrm{C}\right)$ than that inferred from our data in the Kawagebo massif, consistent with differential exhumation between the two valley flanks around this time (Figure 6a). In contrast, the timing of the last phase is similar to the recent phase inferred from our data (Figure 4), and the amount of cooling is comparable or somewhat lower $\left(\sim 30-70{ }^{\circ} \mathrm{C}\right.$ to the east vs. $\sim 50-85^{\circ} \mathrm{C}$ to the west). We conclude that a Quaternary acceleration in cooling is recorded on both flanks of the Mekong valley, even though total exhumation to the east was insufficient to expose samples with Quaternary cooling ages at the surface.

\subsection{Late Miocene Tectonic Forcing in the Mekong Middle Reach}

Late Miocene cooling is both asynchronous and of different magnitude, with the western flank, characterized by high topography in the Kawagebo massif, showing more uplift and exhumation than the eastern flank (Figure 6). We interpret this variable timing and amount of exhumation across the Mekong valley as indicative of a tectonic origin. From our mapping of active faults in the region, we suggest that this late Miocene exhumation is related to a large-scale restraining left-stepping overstep between the Parlung and Zhongdian right-lateral strike-slip faults (Figure 1b). Both these faults are reactivating left-lateral strike-slip faults, as shown by the offsets of both the Salween and Mekong Rivers and the geological units (Figure 2). In the field, no active thrust fault has been identified along the Mekong between the Parlung and the Zhongdian faults. Nevertheless, we suggest that some of the N-trending faults (Figure 2) that were active between the Eocene and early Miocene could have been locally reactivated during the late Miocene within the restraining overstep (Figure 6c). More mapping and detailed thermochronology is needed to identify the structures accommodating the compressive deformation.

\subsection{Rapid Quaternary Incision and the Origin of the Mekong Knickzone}

Rapid Quaternary cooling is indicated by our thermal-history inversion for both flanks of the river valley in the Mekong knickzone, and directly by AHe ages as young as 1.2 Ma on the western flank of the Mekong valley. Our modeling suggests that the valley bottom sample experienced at least 600-900 m more exhumation than the highest sample, implying that rapid Quaternary cooling of our samples is associated with valley incision. Rapid incision of the knickzone is ongoing today, as shown by fluvial terraces that record incision 

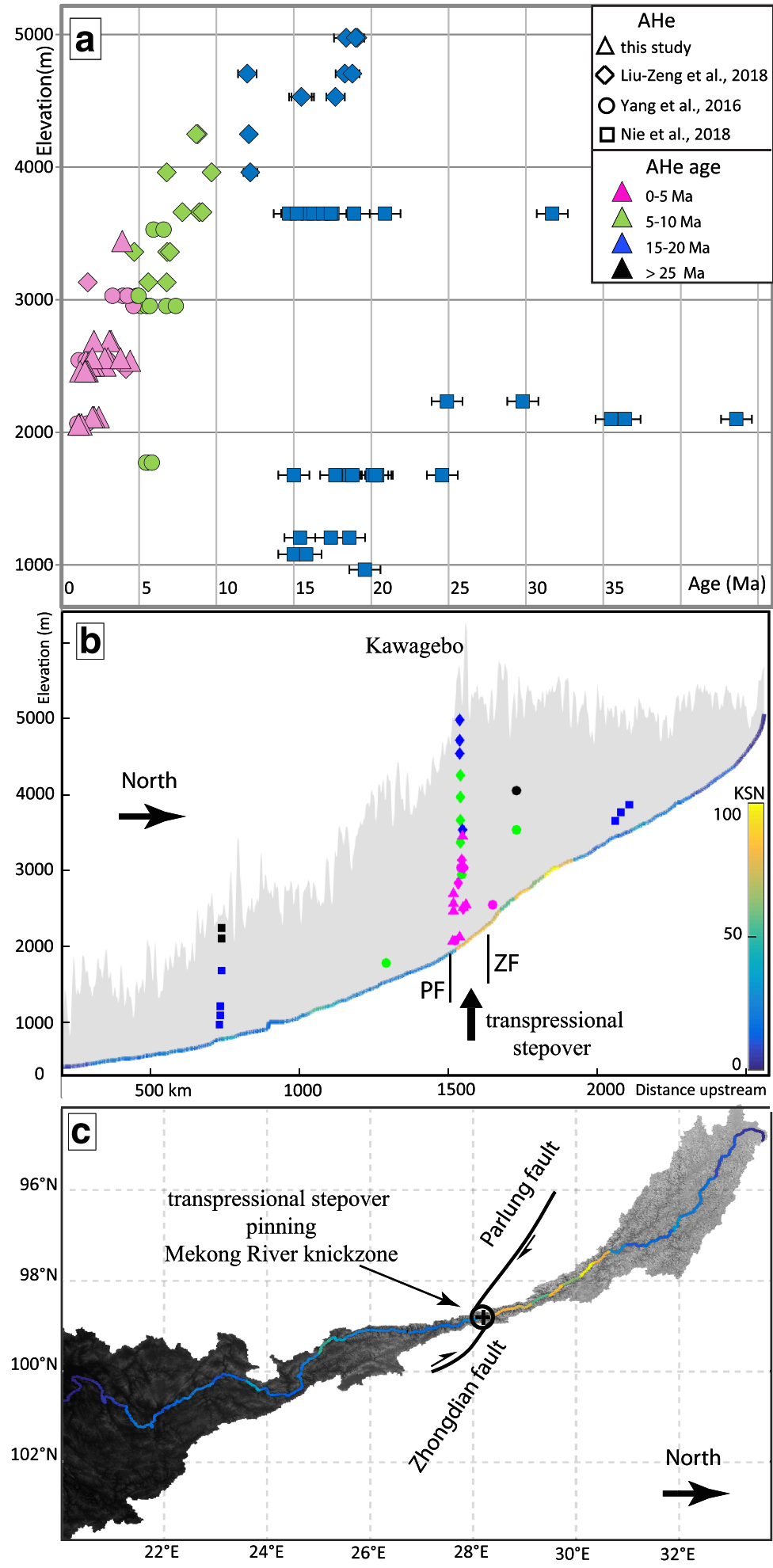

Figure 5. (a) Regional compilation of AHe single-grain ages along the Mekong River shown as an age-elevation plot (see repository material for data); symbols according to authors (for sample locations see Figures 1 and 3) and color according to age. (b) Projection of the samples along the Mekong River (grey shaded area is maximum topography). River profile is colored according to local steepness value $\left(k_{s n}\right)$. Projected locations of the Parlung fault $(\mathrm{PF})$ and Zhongdian fault $(\mathrm{PF})$ are also indicated, showing the transpressional overstep pinning the knickzone. (c) Map of Mekong River catchment with river profile colored according to local steepness value as in panel $b$, showing in map view the transpressional overstep between the Parlung and Zhongdian faults. 


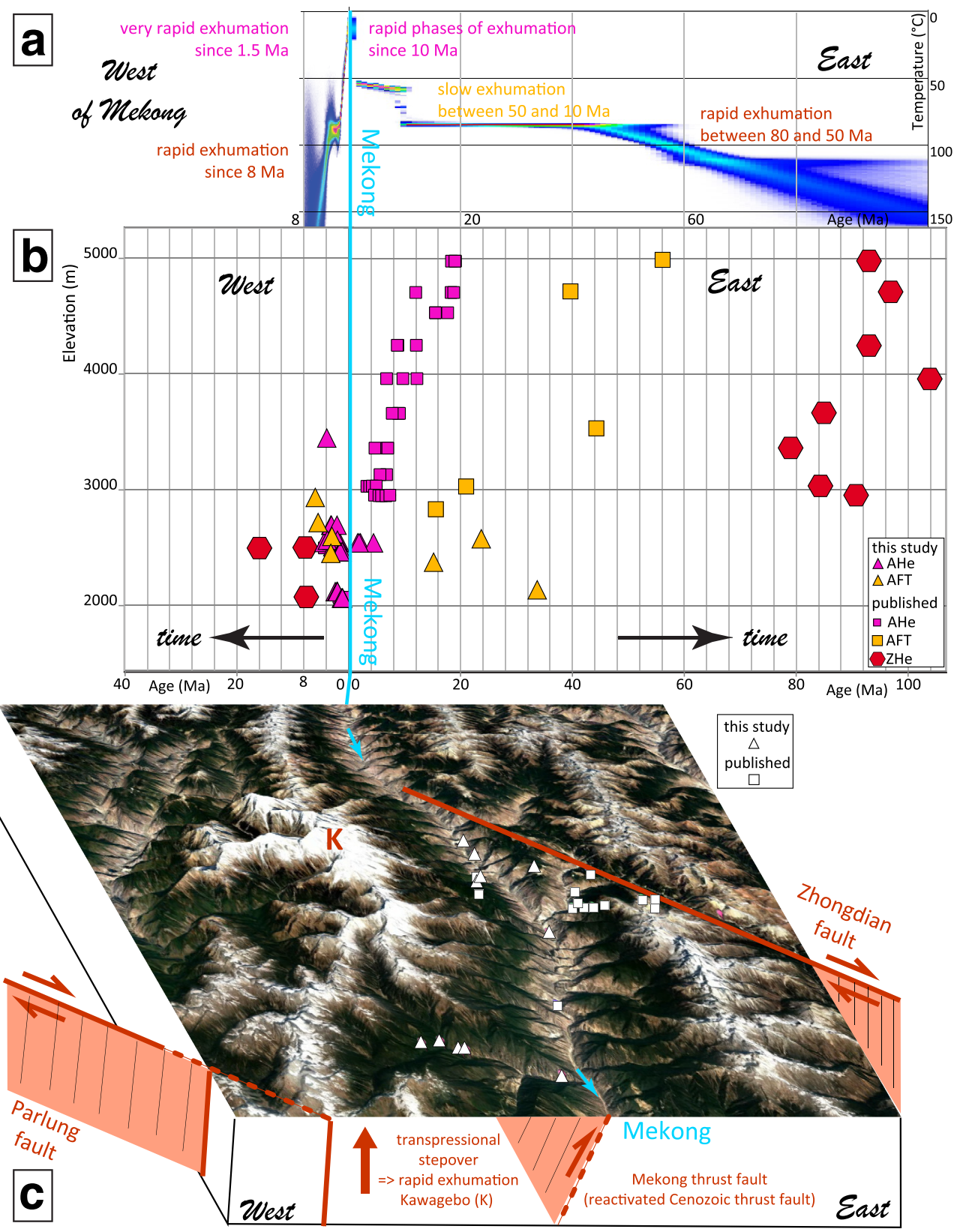

Figure 6. (a) QTQt thermal modeling results on both sides of the Mekong River, with to the west (left) the model presented in this paper (Figure 4) and to the east (right) the model based on data of Liu-Zeng et al. (2018), presented in the supplementary material (repository material), showing the variable amount and timing of exhumation across the Mekong valley. Note that time to the present is going for the west ad to the left for the east side of the Mekong valley. (b) AHe thermochronologic data on both sides of the Mekong River. (c) Schematic 3-D view of the regional topography (from Google Earth) showing the high topography in the Kawagebo massif and the inferred Mekong thrust fault geometry compatible with the regional topography and with thermochronology data. This fault has not been directly observed in the field.

rates of up to $>2 \mathrm{~mm} /$ year since $\sim 100 \mathrm{ka}$ (Zhang et al., 2018). Several potential mechanisms could explain the observed rapid, recent, kilometer-scale incision, and are possibly coupled: a climatically controlled increase in incision rates, transient retreat of the knickzone, or a tectonic control on incision and knickzone location.

It has recently been argued that the incision of the Mekong River is climatically driven (Nie et al., 2018) and rapid Quaternary incision could result from climatic forcing, as has been suggested based on studies of mountainous regions worldwide and including the Himalaya and Eastern Tibet (Clift et al., 2008; Herman 
et al., 2013), although this global signal is currently discussed (Schildgen et al., 2018). Increased incision rates have been unequivocally documented from glacially carved valleys (e.g., Shuster et al., 2005; Shuster et al., 2011; Valla et al., 2011). However, locally within the Kawagebo massif, the maximum Quaternary extent of glaciers, as recorded by glacial valley morphometry and terminal moraines, is restricted to elevations >3,000 m (Figure 3), well above the deep incision described here. Therefore, Quaternary incision of the Mekong valley is fluvial in nature and the increase in exhumation rates is not related to glacial erosion.

Furthermore, young thermochronological ages requiring rapid Quaternary exhumation are clearly restricted to the knickzone reach of the Middle Mekong River and the adjacent anomalously high Kawagebo massif, with older ages encountered at river level both below and above the knickzone (Figure 5). Major knickpoints and knickzones in river profiles can be either transient features, related to upstream-propagating incision after a rapid base-level drop or increase in regional uplift rate, or they can be stable and pinned by rapid localized uplift (Kirby \& Whipple, 2012). Knickpoints and knickzones in rivers incising Southeast Tibet have been interpreted as transient features that record the incisional response to Miocene uplift of the plateau (Clark et al., 2005; Ouimet et al., 2010; Whipple et al., 2017). The pattern of thermochronological ages, younging toward the knickzone in the downstream reach (Yang et al., 2016), is at first order consistent with a retreating knickzone (Braun \& van der Beek, 2004; Safran et al., 2006), although Yang et al. (2016) argued that the knickzone retreat rate required to reproduce the age pattern is much smaller than what would be expected from fluvial incision models. Downstream extrapolation of the Mekong River profile above the knickzone (Kirby \& Whipple, 2012) sets the maximum differential incision across the knickzone (without requiring additional tectonic uplift) to $\sim 1 \mathrm{~km}$. In contrast, the Quaternary exhumation of river-bottom samples required by our data is at least $1.5 \mathrm{~km}$, and more probably $2.1 \pm 0.2 \mathrm{~km}$, whereas upstream incision is predicted to be minimal, $<1 \mathrm{~km}$ since the middle Miocene (Nie et al., 2018) and thus probably less than a few hundred meters during the Quaternary. Therefore, the amount of incision recorded within the Mekong knickzone requires $0.5-1.0 \mathrm{~km}$ of additional tectonic uplift to have taken place in this region.

Local tectonic uplift is also suggested by both the spatial pattern of river steepness and the anomalous topography in the knickzone region. The pattern of steepness values, with high values limited to the knickzone region and similar lower values above and below the knickzone (Figure 5), identifies it as a "vertical-step" knickpoint. These are generally stable features associated with localized increases in rock hardness and/or tectonic uplift rate (Kirby \& Whipple, 2012). As the river flows mainly parallel to major geological units in the region (Figure 2a), there is no obvious variation in lithology associated with the knickzone, suggesting that it is related to spatially focused rock uplift. Such localized uplift could also explain the topography of the Kawagebo massif, standing $\sim 1.5 \mathrm{~km}$ above the average plateau elevation in the region (Figure $6 \mathrm{c}$ ). As for the late Miocene exhumation phase discussed above, we cannot currently point to mapped active structures accommodating this uplift. However, we note that the Mekong River knickzone is limited downstream by the termination of the Parlung fault. Upstream, the knickzone appears to extend to the north of the Zhongdian fault. This would suggest either that there are other active structures north of the Zhongdian fault, or that some of the incision is transmitted upstream (e.g., Koons et al., 2013). We therefore suggest that similar to the late Miocene, Quaternary uplift and incision in this region is controlled by a restraining overstep in this major strike-slip fault system and that the Mekong River knickzone is pinned by active tectonic uplift in this zone (Figs. 5 and 6).

\section{Uplift and Incision in Southeast Tibet}

\subsection{Controls on Incision of the Mekong River}

Existing studies related middle-late Miocene (15-10 Ma) incision of rivers in Southeast Tibet directly to uplift in the region (Clark et al., 2005; Ouimet et al., 2010), but more recent studies have pushed back the onset of incision to at least the early Miocene (20-15 Ma) (McPhillips et al., 2015; Nie et al., 2018; Tian et al., 2014). The drainage pattern, with rivers offset by structures related to the extrusion of Indochina dated between 34 and $17 \mathrm{Ma}$ (Lacassin et al., 1998; Leloup et al., 2001), suggests Oligocene or earlier entrenchment, both in the upstream and downstream reaches of the Mekong River. This timing is consistent with recent reinterpretations of sedimentary, structural, thermochronology, and paleo-altimetry data from the Jianchuan Basin in Southeast Tibet (Figure 2), which suggest that uplift occurred between the Eocene and the early Miocene (Cao et al., 2019;Gourbet et al., 2017 ; Hoke et al., 2014 ; Li et al., 2015 ; Wu et al., 2018). However, this 


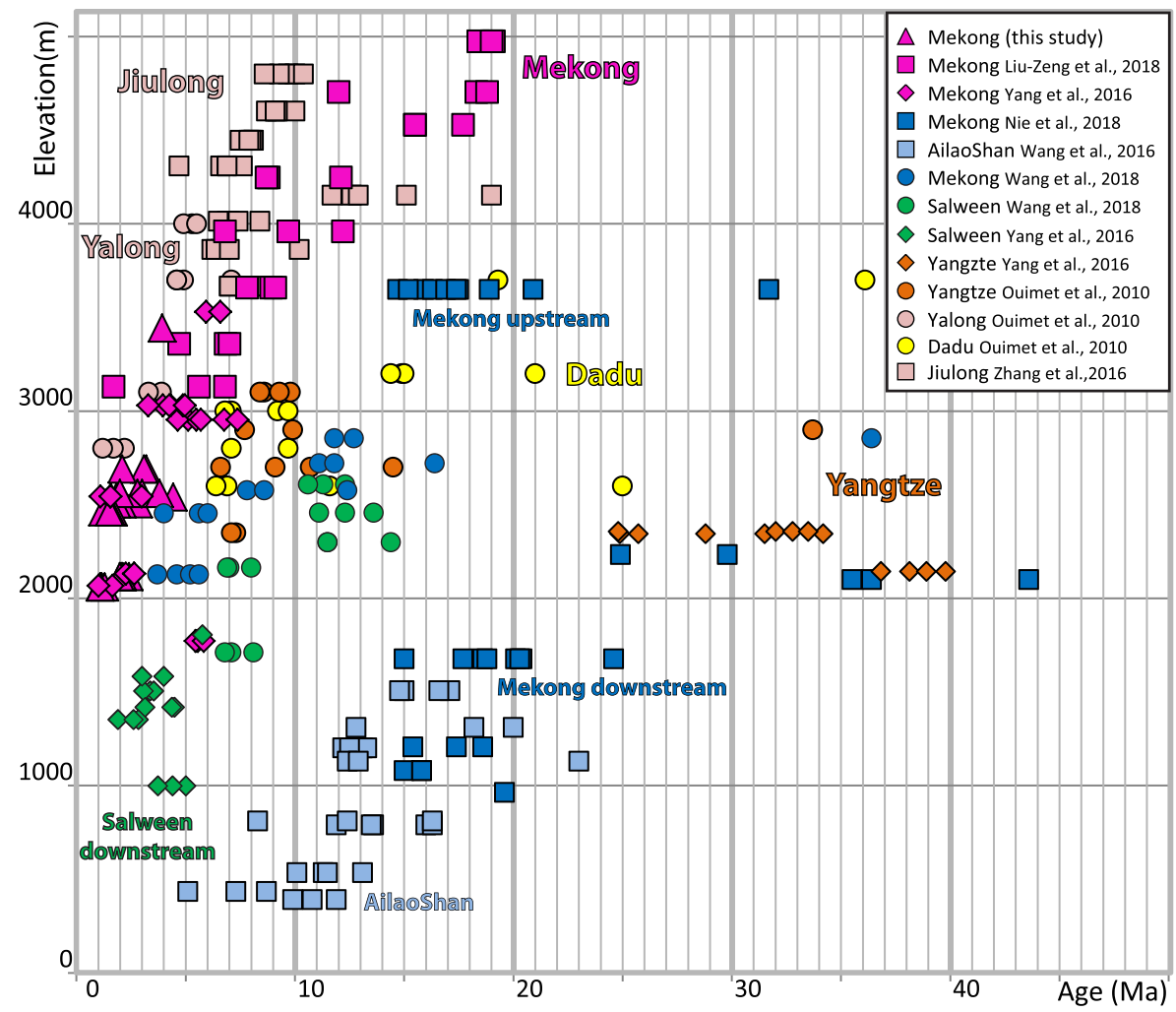

Figure 7. Regional compilation of AHe single-grain ages along vertical profiles (see Figure 1 for localization, with the same color code).

phase of uplift and erosion is not clearly recorded in the thermochronology data. Our modeling of the ageelevation profile near Deqing (data from Liu-Zeng et al. (2018) shows relative thermal stability between $\sim 50$ and $\sim 10 \mathrm{Ma}$ (Figure $6 \mathrm{a}$ ).

Based on the occurrence of early-Miocene AHe ages, mostly between 15 and $20 \mathrm{Ma}$, in the Mekong valley both downstream and upstream of the knickzone (Figure 5), Nie et al. (2018) argued for an early-middle Miocene phase of rapid incision throughout the Mekong River, driven by strong monsoon precipitation between 17 and $14 \mathrm{Ma}$. However, our AHe data from the Mekong knickzone do not record exhumation or incision at that time. The lack of synchronous incision throughout the Mekong River, as shown by our regional synthesis of AHe ages (Figure 5b), casts doubt on an early-middle Miocene (20-15 Ma) climatic origin.

\subsection{Regional Patterns of River Incision}

We combine our AHe results with published ages from the rivers incising Southeast Tibet (Figure 7) in order to assess spatial and temporal patterns of incision at a regional scale. AHe ages collected along the Salween River (Wang et al., 2018; Yang et al., 2016) are 5 Myr older than our Mekong ages for similar elevations. However, all of these samples were collected south of the knickzone in the Salween valley and farther south than our samples. The lack of ages along the knickzone of the Salween River prevents us from directly comparing our results and interpretations obtained for the Mekong River with the Salween River.

The AHe ages observed along the Mekong River near Deqing are similar to AHe ages observed along the Liqiu River, a tributary of the Yalong River, showing a cooling phase starting $>14 \mathrm{Ma}$, constrained by ZHe ages $<14 \mathrm{Ma}$, interpreted as recording the onset of incision of the Yalong River (Ouimet et al., 2010). These ages are also very similar to AHe ages observed above the Jiulong thrust fault branching on the Xianshuihe strike-slip fault (Figure 1a; Zhang et al., 2016). Combined with ZHe ages $<40 \mathrm{Ma}$, these data were interpreted as recording the onset of a phase of thrust activity at $\sim 8 \mathrm{Ma}$, after initial thrusting between $\sim 35$ and $30 \mathrm{Ma}$ (Zhang et al., 2016). The inferred late Miocene phase of thrusting is contemporaneous with the onset of activity of the Xianshuihe fault system at $~ 9$ Ma (Zhang et al., 2017). 
Farther northeast, the Dadu River shows a different age-elevation relationship, with slightly older $(<10 \mathrm{Myr})$ ages than samples from the Yalong and Mekong rivers at similar elevations and some grains being much older, between 50 and $15 \mathrm{Ma}$ (Figure 7). This pattern was interpreted as showing a break in slope at $\sim 10$ Ma, recording the onset of incision of the Dadu River (Clark et al., 2005; Ouimet et al., 2010). The Yangtze River shows a similar age-elevation relationship to the Dadu River, similarly interpreted as recording onset of incision at $\geq 10 \mathrm{Ma}$ (Ouimet et al., 2010). Sampling sites along both of these rivers are located on the high plateau but away from the fault zones (Figures 1 and 2). Therefore, the incision history inferred for the Yangtze and Dadu rivers cannot simply be linked to local exhumation related to a specific fault.

The regional compilation of AHe ages thus supports widespread late Miocene cooling, starting at $~ 8 \mathrm{Ma}$ in the Mekong River (this study; Liu-Zeng et al., 2018), at 10 Ma in the Dadu River (Clark et al., 2005), >10 Ma for the Yangtze River, and >14 Ma for the Yalong River (Ouimet et al., 2010). A moderate increase in cooling rates was also reported for the Salween River at $\sim 8 \mathrm{Ma}$ (Wang et al., 2018). This widespread cooling could be interpreted as recording regional incision, which was however not synchronous throughout Southeast Tibet (Figure 7), as its onset varies between $\sim 8$ and >14 Ma. Farther downstream, the Yangtze River (McPhillips et al., 2015), the Mekong River (Nie et al., 2018), and the Red River in Yunnan (Wang et al., 2016) do not show increased incision since $10 \mathrm{Ma}$ but since 18-14 Ma.

Interpretation of this apparent widespread late Miocene incision as a response to plateau uplift (e.g., Clark et al., 2005; Ouimet et al., 2010) is compounded by the evidence for high elevations in Southeast Tibet since the Eocene-Oligocene (Gourbet et al., 2017; Hoke et al., 2014; Li et al., 2015; Wu et al., 2018). Likewise, the interpretation that such regional incision is linked to a specific climatic event (e.g., Nie et al., 2018) is inconsistent with the observed asynchronous onset. In contrast, some of the major regional faults have been shown to be activated or reactivated contemporaneously with this cooling phase. That is the case of the Xianshuihe fault since $9 \mathrm{Ma}$ (Zhang et al., 2017), the Jiulong thrust since $8 \mathrm{Ma}$ (Zhang et al., 2016), and the Mekong thrust since $\sim 8 \mathrm{Ma}$ (this study). We therefore favor the interpretation of regional fault-controlled uplift around $8 \mathrm{Ma}$ combined with incision of the created topography. Incision could possibly be intensified due to a phase of monsoon intensification at $10 \mathrm{Ma}$ (Nie et al., 2018) but does not appear to be primarily caused by it.

\section{Conclusions}

Our AHe and AFT thermochronology data and thermal modeling show rapid Quaternary cooling of samples located at the bottom and on the west flank of the Mekong valley near Deqing (Figure 3). Our data and models suggest that Quaternary exhumation rates range between 0.6 and $1.4 \mathrm{~km} / \mathrm{Myr}$ (Figure 4), with higher rates for topographically lower samples suggesting that exhumation is at least partly controlled by incision and valley deepening. A higher-elevation transect from the east flank of the Mekong valley (Liu-Zeng et al., 2018) shows similar rapid Quaternary cooling (Figure 6 and repository material). Therefore, both our results and previously published data show a Quaternary increase of incision in the Mekong valley. The regional geomorphology and erosion patterns suggest that Quaternary incision of the Mekong River responds to tectonic forcing over long timescales, due to a restraining left-stepping overstep between the right-lateral Parlung and Zhongdian strike-slip faults that was established during the late Miocene $(\sim 10-8$ Ma). This earlier phase led to differential uplift and exhumation between both flanks of the Mekong valley, uplifting the Kawagebo massif above the mean plateau elevation (Figures 5 and 6). Our results imply no direct link between plateau uplift and river incision but a possible lag-time between both processes (LiuZeng et al., 2008) nor between river incision and climatic variations. They also show that the Mekong knickzone is the expression of locally increased tectonic uplift rates rather than a transient feature related to potential plateau-wide uplift.

\section{Author contributions}

A. R., P. H. L., and P. v. d. B. designed the study; A. R., P. H. L., C. K., Y. Z. Z., and P. v. d. B. performed fieldwork with logistical support from GCW; M. S. J. and C. G. performed AHe analyses; M. B. performed AFT analyses; A. M. performed QTQt modeling; A. R. and P. H. L. performed the tectonic analysis; X. O. performed river long-profile analysis with input from PGV; A. R. and P. v. d. B. wrote the paper with input from all co-authors. 


\section{Acknowledgments}

This study has been supported by the National Special Project on the Tibetan Plateau of the China Geological Survey (1212011121261 and 1212010610103), the National Natural Science Foundation of China (41672195 and 91755213), the China Scholarship Council Funds and the Labex OSUG@2020 (Investissements d'avenir -ANR10 LABX56). Rosella PinnaJamme is thanked for her help during AHe analysis. We thank reviewers Kim Blisniuk and Yang Wang, as well as associate editor Eva Enkelmann, for their helpful comments that improved the manuscript. All the data used are listed in the references or archived in Figshare repository (https://figshare. com/s/10.6084/m9.figshare.11536047).

\section{References}

Bai, M., Chevalier, M.-L., Pan, J., Replumaz, A., Leloup, P.-H., Metois, M., \& Li, H. (2018). Southeastward increase of the late Quaternary slip-rate of the Xianshuihe fault, eastern Tibet. Geodynamic and seismic hazard implications. Earth and Planetary Science Letters, 19-31. https://doi.org/10.1016/j.epsl.2017.12.045

Braun, J., \& van der Beek, P. (2004). Evolution of passive margin escarpments: What can we learn from low-temperature thermochronology? Journal of Geophysical Research, 109, F04009. https://doi.org/10.1029/2004JF000147

Cao, K., Wang, G., Leloup, P.-H., Mahéo, G., Xu, Y., van der Beek, P. A., et al. (2019). Oligocene-Early Miocene topographic relief generation of Southeastern Tibet triggered by thrusting. Tectonics, 38, 374-391. https://doi.org/10.1029/2017TC004832

Clark, M. K., House, M. A., Royden, L. H., Whipple, K. X., Burchfiel, B. C., Zhang, X., \& Tang, W. (2005). Late Cenozoic uplift of southeastern Tibet. Geology, 33, 525-528. https://doi.org/10.1130/G21265.1

Clark, M. K., Schoenbohm, L. M., Royden, L. H., Whipple, K. X., Burchfiel, B. C., Zhang, X., et al. (2004). Surface uplift, tectonics, and erosion of eastern Tibet from large-scale drainage patterns. Tectonics, 23, TC1006. https://doi.org/10.1029/2002TC001402

Clift, P. D., Hodges, K. V., Heslop, D., \& Hannigan, R. (2008). Correlation of Himalayan exhumation rates and Asian monsoon intensity. Nature Geoscience, 1, 875-880. https://doi.org/10.1038/ngeo351

Craw, D., Koons, P. O., Zeitler, P. K., \& Kidd, W. S. F. (2005). Fluid evolution and thermal structure in the rapidly exhuming gneiss complex of Namche Barwa-Gyala Peri, eastern Himalayan syntaxis. Journal of Metamorphic Geology, 23, 829-845. https://doi.org/10.1111/j.15251314.2005.00612.x

Flowers, R. M., Ketcham, R. A., Shuster, D. L., \& Farley, K. A. (2009). Apatite (U-Th)/He thermochronometry using a radiation damage accumulation and annealing model. Geochimica et Cosmochimica Acta, 73, 2347-2365. https://doi.org/10.1016/j. gca.2009.01.015

Fyhn, M. B. W., \& Phach, P. V. (2015). Late Neogene structural inversion around the northern Gulf of Tonkin, Vietnam: Effects from rightlateral displacement across the Red River fault zone. Tectonics, 34, 290-312. https://doi.org/10.1002/2014TC003674

Gallagher, K. (2012). Transdimensional inverse thermal history modeling for quantitative thermochronology. Journal of Geophysical Research, 117, B02408. https://doi.org/10.1029/2011JB008825

Gallagher, K., Brown, R., \& Johnson, C. (1998). Fission track analysis and its applications to geological problems. Annual Review of Earth and Planetary Sciences, 26, 519-572.

Gan, W., Zhang, P., Shen, Z.-K., Niu, Z., Wang, M., Wan, Y., et al. (2007). Present-day crustal motion within the Tibetan Plateau inferred from GPS measurements. Journal of Geophysical Research, 112, B08416. https://doi.org/10.1029/2005JB004120

Gautheron, C., Tassan Got, L., Barbarand, J., \& Pagel, M. (2009). Effect of alpha-damage annealing on apatite (U-Th)/He thermochronology. Chemical Geology, 266, 157-170. https://doi.org/10.1016/j.chemgeo.2009.06.001

Gourbet, L., Leloup, P.-H., Paquette, J. L., Sorrel, P., Mahéo, G., Wang, G., et al. (2017). Reappraisal of the Jianchuan Cenozoic basin stratigraphy and its implications on the SE Tibetan plateau evolution. Tectonophysics, 700-701, 162-179. https://doi.org/10.1016/j. tecto.2017.02.007

Hallet, B., \& Molnar, P. (2001). Distorted drainage basins as markers of crustal strain east of the Himalaya. Journal of Geophysical Research, 106, 13,697-13,709. https://doi.org/10.1029/2000JB900335

Herman, F., Seward, D., Valla, P. G., Carter, A., Kohn, B., Willett, S. D., \& Ehlers, T. A. (2013). Worldwide acceleration of mountain erosion under a cooling climate. Nature, 504(7480), 423-426. https://doi.org/10.1038/nature12877

Hoke, G. D., Liu-Zeng, J., Hren, M. T., Wissink, G. K., \& Garzione, C. N. (2014). Stable isotopes reveal high southeast Tibetan Plateau margin since the Paleogene. Earth and Planetary Science Letters, 394, 270-278. https://doi.org/10.1016/j.epsl.2014.03.007

Ketcham, R. A., Carter, A., Donelick, R. A., Barbarand, J., \& Hurford, A. J. (2007). Improved modeling of fission-track annealing in apatite. American Mineralogist, 92, 799-810. https://doi.org/10.2138/am.2007.2281

Kirby, E., \& Whipple, K. X. (2012). Expression of active tectonics in erosional landscapes. Journal of Structural Geology, 44, 54-75. https:// doi.org/10.1016/j.jsg.2012.07.009

Koons, P. O., Zeitler, P. K., \& Hallet, B. (2013). Tectonic aneurysms and mountain building. In J. Shroder, \& L. A. Owen (Eds.), Treatise on Geomorphology, Tectonic Geomorphology (Vol. 5, pp. 318-349). San Diego, CA: Academic Press.

Lacassin, R., Replumaz, A., \& Leloup, P. H. (1998). Hairpin river loops and slip-sense inversion on southeast Asian strike-slip faults. Geology, 26, 703. https://doi.org/10.1130/0091-7613(1998)026<0703:hrlass >2.3.co;2

Leloup, P. H., Arnaud, N., Lacassin, R., Kienast, J. R., Harrison, T. M., Trong, T. T. P., et al. (2001). New constraints on the structure, thermochronology, and timing of the Ailao Shan-Red River shear zone, SE Asia. Journal of Geophysical Research, 106, 6683-6732. https://doi.org/10.1029/2000JB900322

Leloup, P. H., Harrison, T. M., Ryerson, F. J., Wenji, C., Qi, L., Tapponnier, P., \& Lacassin, R. (1993). Structural, petrological and thermal evolution of a Tertiary ductile strike-slip shear zone, Diancang Shan. Yunnan. J. Geophys. Res., 98, 6715-6743. https://doi.org/10.1029/ 92JB02791

Leloup, P.-H., Lacassin, R., Tapponnier, P., Schärer, U., Zhong, D., Liu, X., et al. (1995). The Ailao Shan-Red River shear zone (Yunnan, China), Tertiary transform boundary of Indochina. Tectonophysics, 251, 3-84. https://doi.org/10.1016/0040-1951(95)00070-4

Li, S., Currie, B. S., Rowley, D. B., \& Ingalls, M. (2015). Cenozoic paleoaltimetry of the SE margin of the Tibetan Plateau: Constraints on the tectonic evolution of the region. Earth and Planetary Science Letters, 432, 415-424. https://doi.org/10.1016/j.epsl.2015.09.044

Liu-Zeng, J., Tapponnier, P., Gaudemer, Y., \& Ding, L. (2008). Quantifying landscape differences across the Tibetan Plateau: Implications for topographic relief evolution. Journal of Geophysical Research, 113, F04018. https://doi.org/10.1029/2007JF000897

Liu-Zeng, J., Zhang, J., McPhillips, D., Reiners, P., Wang, W., Pik, R., et al. (2018). Multiple episodes of fast exhumation since Cretaceous in southeast Tibet, revealed by low-temperature thermochronology. Earth and Planetary Science Letters, 490, 62-76. https://doi.org/ 10.1016/j.epsl.2018.03.011

McPhillips, D., Hoke, G. D., Liu-Zeng, J., Bierman, P. R., Rood, D. H., \& Niedermann, S. (2015). Dating the incision of the Yangtze River Gorge at the First Bend using three-nuclide burial ages. Geophysical Research Letters, 43, 101-110. https://doi.org/10.1002/ 2015GL066780

Nie, J., Ruetenik, G., Gallagher, K., Hoke, G., Garzione, C. N., Wang, W., et al. (2018). Rapid incision of the Mekong River in the middle Miocene linked to monsoonal precipitation. Nature Geoscience, 11(12), 944-948. https://doi.org/10.1038/s41561-018-0244-z

Ouimet, W., Whipple, K., Royden, L., Reiners, P., Hodges, K., \& Pringle, M. (2010). Regional incision of the eastern margin of the Tibetan Plateau. Lithosphere, 2, 50-63. https://doi.org/10.1130/L57.1

Reiners, P. W., \& Brandon, M. T. (2006). Using thermochronology to understand orogenic erosion. Annual Review of Earth and Planetary Sciences, 34, 419-466. https://doi.org/10.1007/978-3-540-48684-8 
Replumaz, A., Lacassin, R., Tapponnier, P., \& Leloup, P. H. (2001). Large river offsets and Plio-Quaternary dextral slip rate on the Red River fault (Yunnan, China). Journal of Geophysical Research, 106, 819-836. https://doi.org/10.1029/2000JB900135

Replumaz, A., \& Tapponnier, P. (2003). Reconstruction of the deformed collision zone between India and Asia by backward motion of lithospheric blocks. Journal of Geophysical Research, 108, 2285. https://doi.org/10.1029/2001JB000661

Safran, E. B., Blythe, A., \& Dunne, T. (2006). Spatially variable exhumation rates in orogenic belts: An Andean example. Journal of Geology, 114, 665-681. https://doi.org/10.1086/507613

Schildgen, T. F., van der Beek, P. A., Sinclair, H. D., \& Thiede, R. C. (2018). Spatial correlation bias in late-Cenozoic erosion histories derived from thermochronology. Nature, 559(7712), 89-93. https://doi.org/10.1038/s41586-018-0260-6

Schoenbohm, L. M., Burchfiel, B. C., \& Liangzhong, C. (2006). Propagation of surface uplift, lower crustal flow, and Cenozoic tectonics of the southeast margin of the Tibetan Plateau. Geology, 34, 813-816. https://doi.org/10.1130/G22679.1

Shuster, D. L., Cuffey, K. M., Sanders, J. W., \& Balco, G. (2011). Thermochronometry reveals headward propagation of erosion in an alpine landscape. Science, 332(6025), 84-88. https://doi.org/10.1126/science.1198401

Shuster, D. L., Ehlers, T. A., Rusmore, M. E., \& Farley, K. A. (2005). Rapid glacial erosion at 1.8 Ma revealed by $4 \mathrm{He} / 3 \mathrm{He}$ thermochronometry. Science, 310, 1668-1670. https://doi.org/10.1126/science.1118519

Valla, P. G., Shuster, D. L., \& van der Beek, P. A. (2011). Significant increase in relief of the European Alps during mid-Pleistocene glaciations. Nature Geoscience, 4, 688-692. https://doi.org/10.1038/ngeo1242

Wang, E., Kirby, E., Furlong, K. P., van Soest, M., Xu, G., Shi, X., et al. (2012). Two-phase growth of high topography in eastern Tibet during the Cenozoic. Nature Geoscience, 5, 640-645. https://doi.org/10.1038/ngeo1538

Wang, Y., Zhang, B., Schoenbohm, L. M., Zhang, J., Zhou, R., Hou, J., \& Ai, S. (2016). Late Cenozoic tectonic evolution of the Ailao ShanRed River fault (SE Tibet): Implications for kinematic change during plateau growth. Tectonics, 35, 1969-1988. https://doi.org/10.1002/ 2016TC004229

Wang, Y., Zhang, P., Schoenbohm, L. M., Zheng, W., Zhang, B., Zhang, J., et al. (2018). Two-phase exhumation along major shear zones in the SE Tibetan Plateau in the Late Cenozoic. Tectonics, 37(8), 2675-2694. https://doi.org/10.1029/2018TC004979

Wilson, C. J. L., \& Fowler, A. P. (2011). Denudational response to surface uplift in east Tibet: Evidence from apatite fission-track thermochronology. Geological Society of America Bulletin, 123, 1966-1987. https://doi.org/10.1130/B30331.1

Wu, J., Zhang, K., Xu, Y., Wang, G., Garzione, C. N., Eiler, J., et al. (2018). Paleoelevations in the Jianchuan Basin of the southeastern Tibetan Plateau based on stable isotope and pollen grain analyses. Palaeogeography Palaeoclimatology Palaeoecology, 510, 93-108. https://doi.org/10.1016/j.palaeo.2018.03.030

Yang, R., Fellin, M. G., Herman, F., Willett, S. D., Wang, W., \& Maden, C. (2016). Spatial and temporal pattern of erosion in the Three Rivers Region, southeastern Tibet. Earth and Planetary Science Letters, 433, 10-20. https://doi.org/10.1016/j.epsl.2015.10.032

Yang, R., Willett, S. D., \& Goren, L. (2015). In situ low-relief landscape formation as a result of river network disruption. Nature, 520(7548), 526-529. https://doi.org/10.1038/nature14354

Zhang, H., Oskin, M. E., Liu-Zeng, J., Zhang, P., Reiners, P. W., \& Xiao, P. (2016). Pulsed exhumation of interior eastern Tibet: Implications for relief generation mechanisms and the origin of high-elevation planation surfaces. Earth and Planetary Science Letters, 449, 176-185. https://doi.org/10.1016/j.epsl.2016.05.048

Zhang, J.-Y., Liu-Zeng, J., Scherler, D., Yin, A., Wang, W., Tang, M.-Y., \& Li, Z.-F. (2018). Spatiotemporal variation of late Quaternary rive incision rates in southeast Tibet, constrained by dating fluvial terraces. Lithosphere, 10, 662-675. https://doi.org/10.1130/L686.1

Zhang, Y.-Z., Replumaz, A., Leloup, P.-H., Wang, G.-C., Bernet, M., van der Beek, P., et al. (2017). Cooling history of the Gongga batholith Implications for the Xianshuihe Fault and Miocene kinematics of SE Tibet. Earth and Planetary Science Letters, 465, 1-15. https://doi. org/10.1016/j.epsl.2017.02.025

Zhang, Y.-Z., Replumaz, A., Wang, G.-C., Leloup, P.-H., Gautheron, C., Bernet, M., et al. (2015). Timing and rate of exhumation along the Litang fault system, implication for fault reorganization in Southeast Tibet. Tectonics, 34, 1219-1243. https://doi.org/10.1002/ 2014TC003671 